\title{
THE DYNAMICS OF THE INDONESIAN HADRAMIS ON THE MAULID CELEBRATION
}

\author{
Muhammad As'ad \\ Radboud University, Nijmegen and Universitas Hasyim Asy'ari, Jombang \\ muhammad.asad@tebuireng.net
}

\begin{abstract}
This article seeks to explore the debate between two groups of Indonesian Hadhramis (Bā 'Alawi and nonSayyid) concerning the maulid celebration. It is based on a qualitative research study. The data was collected through a combination of library research and field study. The fieldwork was completed in Surakarta by observing the maulid celebration of the Bā 'Alawi community in the city. The study results show the debate between the Sayyid and non-Sayyid communities surrounding the maulid has occurred since the early $20^{\text {th }}$ century and continues until today. The first group, also known as the Bā 'Alawi, have consistently supported the maulid practice since the early $20^{\text {th }}$ century, starting with the establishment of Jamiat Khair to several Bā 'Alawi preachers such as the ones in the Riyadh Mosque in Surakarta that are explained in this text. Regarding the second group, the maulid is promoted by the Al-Irsyad faction, which do not condemn the maulid but only criticize some practices within the celebration they regard as bid'a. In the present day, Al-Irsyad is separated into two groups: Al-Irsyad AlIslamiyah and the Salafis of Perhimpunan al-Irsyad. This
\end{abstract}


article finds that the former preserves the old stance of the organization regarding the maulid. However, the latter has a stricter teaching on the maulid, stating it is bid' $a$ and recommends its members and followers not to practice it.

Keywords: the maulid celebration, Hadrami, Bā 'Alawi, Al-Irsyad, debate.

\section{A. Introduction}

Hadhramis are an Arab people originating from the Hadhramaut region in Yemen. Their diasporic communities can be found around the world, including in Southeast Asia. Most Hadhramis arrived in the Dutch East Indies, present-day Indonesia, in the latter half of the eighteenth century (L.W.C. van den Berg, 1989; Mobini-Kesheh, 1999).

In terms of social status, Indonesian Hadhramis are categorized into two groups. The first group is the Sayyid (pl. sada) community who claim to be descendants of Prophet Muhammad (peace be upon him). Also referred to as the Bā 'Alawi, or "children of 'Alawī," they embrace the 'Alawìyya Sufi order and the Shafi'i madhhab (Islamic school of law). The second group is the non-Sayyid community. They occupy a lower social rank than the Sayyids as they cannot claim lineage from the Prophet (pbuh). When the Hadhrami people left Hadhramaut, they brought this stratification with them to their new lands. Furthermore, it should be noted that differences between the Bā 'Alawi and the non-Sayyid not only in social life but also in religious discourse. 
This article will discuss the dynamics between these two groups, especially concerning the debate around the maulid celebration. There are several recent works regarding the Hadhramis. Among them are those of Ismail Fajrie Alatas, whose master's thesis (2009) explored the development of the Bā 'Alawī in post-independence Indonesia. Additionally, he produced several articles $(2011,2014)$ and a doctoral thesis (2016) concerning the Bā 'Alawì. In the two-former works, Alatas discusses the Tariqa Alawiyya in the post-colonial era and the creation of haul, an annual death commemoration which has transformed from not only being a Bā 'Alawī festivity but also into a kind of public expression of Islam. In the latter work, Alatas describes the formation of Islamic religious authority, focusing on Bā 'Alawi figures such as Habib Lutfi bin Yahya from Pekalongan, Central Java. Similar to Alatas, Martin Slama has also written several articles with regard to the Bā 'Alawī $(2011,2014)$. In the first work, Slama compares Hadhrami groups on Sulawesi and on Java. While in the second, Slama discusses the up-and-down relationship between Hadhramis in Indonesia and their network in Hadhramaut. However, the works of both Alatas and Slama have thus far not explored the debate between the Sayyid and non-Sayyid in relation to the maulid.

Regarding the dynamics of the non-Sayyid community, Miftahuddin (2013) and Syamsul (2017) address the development of Al-Irsyad in the post-reformation era. These two works capture how the debate between the two factions of Al-Irsyad led to the creation of two separate organizations: Al-Irsyad Al-Islamiyah and Perhimpunan al-Irsyad. Yet, these two works did not discuss the dispute between the two bodies 
dealing with a religious opinion, especially their stances surrounding the maulid celebration. In general, this study will fill the literature gap on the Hadhramis of Indonesia, particularly by giving information and analysis on the dynamic between the Sayyid and non-Sayyid pertaining to the maulid.

This article is based on a qualitative research study that combined library research and fieldwork. The library research was done by scrutinizing recent studies on the Hadhramis to find an explanation on their positions in connection with the celebration of maulid. The fieldwork was done in Solo in the span of two months from January to February 2018 by observing the maulid celebration at the Riyadh Mosque. In general, this article argues that the debate between the Sayyid and the non-Sayyid that exists today has occurred since the early $20^{\text {th }}$ century. This article finds that the opinion of the non-Sayyid community related to the maulid is not a singular one. The Salafi faction is against celebrating the maulid, while reformists accept the celebration with some modifications.

This article will firstly discuss the historical background of Hadhramis in Indonesia and the dynamics within their community. The section afterward will discuss the different standpoints taken by Indonesian Hadhramis, particularly with regard to religious rituals, including the maulid celebration. The last two sections will discuss the reaction of the Bă 'Alawi to criticism of the maulid by the non-Sayyid community and how they are able to revive their network and movement to promote the maulid celebration amid the intense criticism. The last section will discuss the maulid celebration in Surakarta as part of the Bā 'Alawi's efforts to preserve and promote the maulid in the city. 


\section{B. The History of Hadrami Dynamics in Indonesia}

As it is explained by several scholars such as Bujra (1967), Haikal (1986), Huub de Jonge (1993), and MobiniKesheh (1999), Hadhramis, especially the Bā 'Alawi, place great importance on preserving their cultural and religious traditions. They have a common belief that they are the biological heirs of the Prophet (pbuh). Additionally, they practice kafä'ah (equality) in marriage, meaning that Bā 'Alawi women can only marry men inside their community. When the Bā 'Alawi settled in the Dutch East Indies, this tradition was maintained. In addition, certain honorific names continue to be used by the Bā 'Alawi: 'Sayyid' and 'Habib' for men, and 'Syarifah', 'Habiba,' or 'Sayyida' for women (Boxberger, 2002; Mobini-Kesheh, 1999).

In her work about the Hadhrami people in the Dutch East Indies, Mobini-Kesheh (1999) states that in the early decades of the $20^{\text {th }}$ century, the Hadhramis progressed through education, organization, and literacy in a way that she describes as nahdah (an awakening). This can be seen, for instance, in the establishment of the Jamiat Khair in 1901 (Haikal, 1986). As an organization initiated by the Bā 'Alawi, most of its boards were Sayyids. However, the organization also consisted of non-Sayyid members who joined but only became passive members uninvolved in the board structure. One of the reasons for the establishment of such an organization was the lack of opportunity Arabs had in obtaining a formal education (Noer, 1963). To encourage the progress of its educational institution, Jamiat Khair invited several teachers from the Middle East. One teacher, Syaikh Ahmad Surkati (d. 1943), was a Mecca-educated Sudanese man familiar with the 
works of Muhammad Abduh and Rashid Ridha. Consequently, he favored the idea of ijtihād and was against the practice of taqlìd (Islamic reformism) (Abu Shouk, 2002).

In 1911, Surkati was brought to Java by Jamiat Khair to be its schools' inspector. After two years, the organization, pleased with his work, gave Surkati full authority to appoint teachers for its schools. Thus, Surkati requested more Sudanese individuals to help him with assessing the schools (Mobini-Kesheh, 1999; Noer, 1973). Alongside Surkati, the new teachers promoted the notion of Islamic reformism to the schools, as well as to the organization (Abu Shouk, 2002; Mobini-Kesheh, 1999; Noer, 1963). The strong influence of Surkati worried some people in Jamiat Khair, especially his appreciation of Islamic reformism. One of their objections lied in Surkati's belief that all Muslims were equal and that higher status could not be imparted on a person due to their lineage. Naturally, Surkati's point of view would threaten the social status of the Bā 'Alawi (Abu Shouk, 2002).

The falling-out between Surkati and Jamiat Khair would occur after an incident in Solo, Central Java, in 1913. The Bā 'Alawi objected to Surkati's suggestion of a marriage match between a syarifah (a daughter of a Sayyid) with a non-Sayyid man. Such a union was disapproved of as it went against the Bā 'Alawi interpretation of kafä'ah. Following that event, the relationship between Surkati and Jamiat Khair deteriorated. The Bā 'Alawi accused Surkati of advocating anti-Sayyid sentiment and opposing the teaching of Shafi'ì madhhab (Mobini-Kesheh, 1999; Noer, 1963).

Surkati's firm stance on certain religious opinions, like that in the instance above, would result in his forced resignation 
from Jamiat Khair in 1914. The resignation of Surkati was then followed by the resignation of several of his followers within the organization, both non-Sayyid and Sayyid, who had shared the same views. Subsequently, Surkati and his followers established a new school, the Madrasah al-Irshad al-Islamiyyah (Islamic School for Guidance). This school was then converted into a foundation with the name of Jam'īyyah al-Islāh wa al-Irsyād al'Arabiyyah (Arab Association for Reform and Guidance). Known as Al-Irsyad, the Colonial Government recognized the school in 1915 (Mobini-Kesheh, 1999).

In general, the establishment of Al-Irsyad shows the attempt of Surkati and the reformist Hadhramis to contest the religious authority of Jamiat Khair, especially the Bā 'Alawi. Throughout history, the authority of the Bā 'Alawi was believed without objection. This was due to the widespread belief that they are the descendants of the Prophet (pbuh). Departing from Islamic reformism, Surkati changed this idea by stressing Islamic orthodoxy through the revival of sunnah and the abandonment of bid'a (innovation). Surkati desacralized the title of 'Sayyid', a title originally claimed could only be used by the Bā 'Alawi. For Al-Irsyad and Surkati, the title 'Sayyid' was not a privilege reserved for the Bā 'Alawi (MobiniKesheh, 1999). The conflict between the two factions on this issue lasted for years, and the debate between them would be fought out in the publications of both groups. The fierce dispute between Jamiat Khair and Al-Irsyad demonstrates the quarrel over religious authority between the traditional Bā 'Alawi with the reformist Muslims of Al-Irsyad. 


\section{Al-Irsyad Criticism on the Maulid Celebration}

In this section, I will explain the criticism of Al-Irsyad on the Bā 'Alawi's religious rituals, including the maulid celebration.

\section{Religious opinion of Ahmad Surkati}

Besides the criticism of Surkati and Al-Irsyad on the Bā 'Alawi's religious practices elaborated in the previous section (the kafä'ah and the use of the Sayyid title), several other religious practices and beliefs are criticized by AlIrsyad. For example, a book by Surkati titled Al-Masā'il al-Thalāth (The Three Problems) discusses these issues. Surkati wrote this book after receiving an invitation to a debate. The debate was supposed to revolve around the three following topics: ijtihād (individual reasoning) and taqlīd (blind obedience), gravesite visitation and tawassul (intermediation), and sunnah and bid'a. However, as the person who called for the debate did not show up, Surkati decided to publish the book as a response (Surkati, 1988).

As a reformist Muslim, Surkati always based his criticisms on the Qur'ān and hadīth. In explaining the three problems, he consistently pointed to the direct sources of the Qur'ān and hadìth, instead of the opinion of the ulamā. Therefore, with regard to the first topic of ijtihād and taqlīd, Surkati favored the former. In his book, he criticizes those who practiced blind obedience (muqallid) as he considers them not in line with the salaf al-sālih (the first three generations of Muslims) who did not practice taqlīd. According to Surkati, the salaf al-sālih tried to directly understand the Qur'ān and sunnah and not follow other Muslims' interpretation of these sacred 
texts (Surkati, 1988). Naturally, his opinion is consistent with the typical reformist Muslim thinking that advocates returning to the Qur'ān and sunnah by practicing ijtihād.

Regarding gravesite visitation and tawassul, Surkati argues that visiting the grave is recommended by the Prophet (pbuh). However, the visit should exclude forbidden practices such as crying at the grave, tawassul, saint worshipping, seeking a blessing from the deceased, or making a sacrifice with the intention of being rewarded by the grave. He states that all these practices are considered shirk (idolatry) (Surkati, 1988). However, Surkati put emphasis on one particular custom widely practiced in the Dutch East Indies. This custom was saint worship, in which Muslims conducted a ritual around the grave by overpraising the deceased to garner a blessing to the visitors. Surkati considers the ritual a pagan practice, and he suggested Muslims avoid it as God forbids pagan practices (Surkati, 1988). It seems that this criticism was directed toward the Bā 'Alawi, who believe in a cult of saints.

Concerning tawassul (intermediation), Surkati regards this practice as munkar (evil). The basis for this condemnation is that, according to Surkati, neither the Prophet (pbuh) nor his companions practiced this ritual. He also states that the four madhhab founders did not practice tawassul either. Therefore, in his opinion, this ritual must be avoided (Surkati, 1988). Again, this criticism is presumably directed toward the Bā 'Alawi, who practice the ritual of tawassul in almost every religious gathering they hold. 
On the third topic of sunnah and bid'a, Surkati firstly explains the definition of sunnah, which he regards as the Prophet's (pbuh) utterances and deeds aimed at explaining the verses of the Qur'ān. He then explains that Islam came from the Almighty Allah and was brought by Prophet Muhammad (pbuh). Therefore, in his opinion, there must be no addition by Muslims with regard to religious rituals. He also emphasizes that any addition to this 'perfect religion' can be considered bid'a and will lead people astray. In addition, Surkati also mentions that there can be no bid'a hasanah (good innovation), especially in religious matters (Surkati, 1988). Nevertheless, there were some religious practices of Muslims in the Dutch East Indies that were considered bid'a by Surkati. They are ushalli (uttering the intention), talqin (reciting when someone is about to die or after the burial), the practicing of tahlilan (praying for the deceased), and visiting the grave and al-qiyām fi qissat maulid an-nabi (the act of standing in the maulid celebration) (Affandi, 1976).

Regarding the maulid, it seems that Surkati did not reject the maulid celebration. As mentioned above, Surkati considered the act of qiyām during the maulid celebration as bid'a. Yet, he did not mention anything about the celebration itself. His religious stance on this issue can be confirmed by a maulid event that took place in Batavia in 1919. The maulid celebration was reported to be attended by some Irsyadis. However, when the participants of the maulid stood up during the qiyām, the Irsyadis remained sitting. Many Muslims criticized the actions of these Irsyadis in Batavia (N. Kaptein, 1993). 
This occurrence provides us with valuable evidence that Surkati and the Irsyadi did not reject the celebration of the Prophet's birthday; instead, they only rejected the practice of the qiyām during the recitation. Moreover, this religious stance can be further supported by a report about a school belonging to Al-Irsyad celebrating the Prophet's birthday with a performance from the Boy Scouts in 1938 and 1939 (Mobini-Kesheh, 1999).

The position of Ahmad Surkati and Al-Irsyad on the maulid celebration is in line with Muhammadiyah figures such as Abdul Karim Amrullah, also known as Haji Rasul (d. 1945). Muhammadiyah (and Haji Rasul) did not forbid the celebration of the Prophet's birthday, as long as it kept in compliance with Islamic law. The only practice surrounding the maulid that was objected to by Haji Rasul was the qiyām. However, Muhammadiyah shifted its stance on the maulid, allowing the reciting of the maulid book of Barzanji in 1986. Although, in the first decade of the $21^{\text {st }}$ century, the organization forbade its members to recite the maulid book (As'ad, 2019).

\section{The Break of al-Irsyad}

What can be said about Al-Irsyad in recent times? Have they shifted their stance on the maulid as their fellow reformists the Muhammadiyah have? Al-Irsyad, recently split into two institutions: the first being Al-Irsyad AlIslamiyah and the second being Perhimpunan Al-Irsyad. The schism of Al-Irsyad can be attributed to Salafi influences on the organization. The division began at one pondok pesantren (Islamic boarding school) of Al-Irsyad in 
Tengaran, Central Java, which has been occupied by Salafi religious teachers (ustad). The pesantren had been built by funding from Saudi Arabia. When it was finished, the Saudi government representative requested that Salafi teachers run the institution. Three ustads were appointed to teach and lead the pesantren: Ja'far Umar Thalib (b. 1961), Abdul Qadir Jawas (b. 1962), and Yusuf Usman Baisa (n.d.). These three teachers were all Hadhramis who were educated in the Middle East (Hasan, 2006).

The introduction of these teachers resulted in significant changes to the pondok pesantren and the organization itself. Concerning the pondok pesantren, the curriculum was adapted according to Salafi teaching. These ustads strictly implemented Salafi principles such as the prohibition of human and animal pictures, no paying respect to the national flag, no smoking or watching television, as well as the banning of music. These doctrinal rules concerned parents who noticed their children implementing at home the teaching of removing pictures, television, and radio they had received at the pesantren. Subsequently, the parents filed a formal complaint about this. After a meeting which was attended by the central board of Al-Irsyad, it was decided that the three Salafi teachers needed to be replaced. Following that decision, for a while, the pondok pesantren lacked leadership. As a result, the branch of Al-Irsyad in Semarang re-appointed one of the teachers, Yusuf Usman Baisa (n.d.), as the pesantren's director (Hasan, 2006). From this point on, Salafi's teaching had a strong reception among the AlIrsyad's various branches, especially among the younger 
generations. Accordingly, many branches of Al-Irsyad invited Salafi ustads such as Abdul Qadir Jawas (b. 1962) to give lectures (Miftahuddin, 2013). The spread of Salafi influences angered the central board of Al-Irsyad. This resulted in the issuance of a letter of dismissal by the then chairman of Al-Irsyad, Geys Amar (n.d.), to ten other central board members, including his vicechairman Muhammad Bawazir (n.d.). These ten board members were regarded as adherents of Salafi thinking. Thus, according to Geys Amar, the dismissal of these ten members was intended to protect Al-Irsyad from SalafiWahabi influences (Rijal, 2017). By doing this, he wanted to keep the reformist-modernist style of Al-Irsyad as how Ahmad Surkati founded it.

This dismissal was related to the second significant change in the organizational structure of Al-Irsyad. The Al-Irsyad members who disagreed with the dismissal decision held a significant congress in 1999. This congress resulted in the new Salafi faction of the Al-Irsyad central board. There were several attempts of reconciliation between these two factions of Al-Irsyad. However, all of these attempts failed. The conflict was then settled in court, with the court deciding in favor of the reformist faction. As a reaction to this defeat, the Salafi faction established a new organization called 'Perhimpunan Al-Irsyad' (Al-Irsyad Association). It was registered to the Ministry of Law and Human Rights in 2013. As can be seen from its name, this new organization still uses the word 'Al-Irsyad' with some modifications, especially to the old logo of Al-Irsyad (Rijal, 2017). Meanwhile, the 
reformist faction kept its original name of Al-Irsyad AlIslamiyah as Surkati registered it.

As put forward by Rijal (2017), this separation shows the struggle for authority between the reformist and Salafi factions of Al-Irsyad. The reformist faction mostly consists of the older generation, who wanted to maintain the organization's reformist-modernist style. According to them, the Salafi-Wahabi influences pose a threat to Al-Irsyad. They say these teachings were brought in by the younger generation of Al-Irsyad, who were educated at Salafi institutions in Indonesia and the Middle East. In response, Al-Irsyad Al-Islamiyah recently published a manual explaining the Al-Irsyad identity, which emphasizes the combination of religious knowledge and modernity (Rijal, 2017).

The other faction, Perhimpunan Al-Irsyad, wants to emphasize the purity of the organization by implementing strict religious interpretation, which includes separating boysand girls in school. They rejecttheolder interpretations of Al-Irsyad, stating that they are influenced by the ideas of liberalism and pluralism (Rijal, 2017). Nowadays, many new Salafi ustads join Perhimpunan Al-Irsyad. These ustads, such as Firanda Andirja Abidin (b.1979), Khalid Bassalamah (b.1975), and Syafiq Bassalamah (b.1974), enjoy large followings on social media (Perhimpunan Al-Irsyad, 2019). They graduated from universities in Saudi Arabia and are positioned at the fatwa board of Perhimpunan Al-Irsyad. Firanda, who had led the board, graduated from the Islamic University of Madinah (Perhimpunan Al-Irsyad, 2019). 


\section{Different Interpretation of al-Irsyad on the Maulid Celebration}

Pertaining to the schism of Al-Irsyad into Perhimpunan Al-Irsyad and Al-Irsyad al- Islamiyah, each of them offers a different interpretation on the legality of certain religious rituals, including the maulid celebration. This section will discuss each organization's opinion regarding the maulid celebration.

The opinion of Perhimpunan Al-Irsyad on the maulid can be seen through the statements of some members of the fatwa board of Perhimpunan Al-Irsyad on social media. As these preachers are quite famous online, their statements could be easily found. The first statement is from Firanda Andirja Abidin, the chairman of the fatwō board of Perhimpunan Al-Irsyad. This statement is a response to a question by one of his followers on the ruling of the maulid celebration. Firanda's argument is as follows:

The maulid celebration is a religious ritual that was done neither by the Prophet (pbuh) nor his companions. Due to this reason, we do not practice the maulid celebration. Some people say that the maulid is celebrated because they love the Prophet, but the companions had a bigger love for the Prophet (pbuh) than us. However, they never celebrated the maulid (Salam Dakwah, 2014).

From the above statement, we can see that Firanda rejects the maulid celebration. Besides this statement, there are several other lectures of Firanda on social media where he states that the maulid celebration is bid'a and recommends to his followers not to practice it (Muslim Belajar, 2017; Tauhid Squad, 2016). 
In addition to Firanda, another member of the fatwa board of Perhimpunan Al-Irsyad, Khalid Bassalamah, made the same argument on social media. When asked by one of his followers whether he was permitted to join the maulid celebration at the invitation of a friend, Bassalamah stated that he should not go as the maulid was never practiced by the Prophet (pbuh) (Hijrah, 2016).

Turning now to the opinion of Al-Irsyad AlIslamiyah on the maulid, unfortunately, an official stance by the organization was unable to be found. However, some examples offer insight into what that stance could be. The first is a statement by the chairman of Al-Irsyad AlIslamiyah during the maulid celebration in Jakarta in 2017. He states that the maulid celebration is commemorated not only to celebrate the Prophet's birthday but also to convey Islam as a religion that blesses the universe (Islam rahmatan lil 'Alamin) (Republika, 2017). Another example can be found on the Facebook page of an AlIrsyad Al-Islamiyah primary school in Jember, East Java. On its Facebook page, the school posted about a speech contest for students that will be held to celebrate the maulid (Al-Irsyad, 2017).

From these two examples, we can conclude that AlIrsyad Al-Islamiyah does not reject the celebration of the Prophet's birthday. The organization even celebrates it with some religious events, as seen in the example of the primary school. However, it seems that the maulid events celebrated by Al-Irsyad Al-Islamiyah are not the same as those of Nahdlatul Ulama, whose events include reciting the maulid book of Barzanjī. It can be inferred that Al- 
Irsyad Al-Islamiyah follows the fatwā of Surkati who only rejects the practice of qiyām during the maulid, but not the celebration itself.

By comparing Perhimpunan Al-Irsyad and AlIrsyad Al-Islamiyah, we can see that the two organizations have different religious positions regarding the maulid celebration. The former rejects the ritual by stating it is bid' $^{\prime}$, and therefore, Muslims must not practice it, while the latter does not condemn the celebration. Al-Irsyad Al-Islamiyah celebrates the maulid by replacing the maulid recitation with religious lectures and gatherings. However, in terms of religious discourse, Perhimpunan Al-Irsyad has a greater significant impact on Indonesian Muslims. This can be seen in the many video lectures and articles by members of the fatwa board of Perhimpunan Al-Irsyad that can be found on the internet (Lentera Islam, 2016; Sang Pendoa, 2017). Furthermore, these fatwā board members routinely discuss and give their followers suggestions on certain rituals they deem bid'a. This is different from Al-Irsyad Al-Islamiyah, whose preachers I could not find many online videos or articles.

\section{The Revival of Bā 'Alawi in Indonesia}

This section analyzes how the Bā 'Alawi reacted to and defended the Salafi Hadhramis against criticism made toward them in regard to the maulid celebration.

\section{Revitalizing the Yemeni connection}

From the work of van den Berg (1989) and MobiniKesheh (1999), we learn that a substantial number of 
Hadhramis came to Indonesia in the latter half of the $18^{\text {th }}$ century. The number of Hadhramis in Indonesia drastically increased in the $19^{\text {th }}$ and $20^{\text {th }}$ centuries, from only 4.992 people in 1859 (Java only) to 80.000 people in 1942 (Mobini-Kesheh 1999). In the later period, the connection between Indonesia and Hadhramaut was sustained through the Hadhrami diaspora in Indonesia's preference to send their children to Hadhramaut to study Islam. This relation was halted in 1967 due to Yemen's political situation, which involved its Southern region being occupied by a communist regime. As a consequence, the anti-communist Soeharto restricted migration between Indonesia and Yemen. This policy naturally altered the network connection between Hadhramaut and its diasporic community in Indonesia. The last migration from Hadhramaut to Indonesia was in the 1950s (Slama, 2014).

When the communist regime collapsed, and the two states of South and North Yemen were united in 1990, the connection between Indonesia and Hadhramaut was revived. There are two factors responsible for this revival. The first was the emerging charismatic preacher Habib Umar bin Hafiz (b. 1963). Since 1996, he has accepted many students from Indonesia and became the patron of many Bā 'Alawi figures in this country. The second factor was the Indonesian Bā 'Alawi's desire to reconnect with the land of its ancestors (Rijal, 2017).

Related to the first factor, Habib Umar is a son of a respected Bā 'Alawī' ulamā' in Hadhramaut. His father was killed during the communist regime that forced him to leave the country and stay in Saudi Arabia while studying. He returned 
to Yemen after the unification in 1990 and then established his madrasah of Darul Mustafa in Tarim, Hadhramaut in 1996. One of the madrasah's aims is to maintain and protect the Bā 'Alawi's religious tradition, such as the daily recitation of the maulid book and the visit to the sacred tombs (Knysh, 2003). According to Knysh (2003), the emergence of Habib Umar and Darul Mustafa was a reaction to the growing development of their Salafi counterpart in north Yemen. This Salafi group was led by Shaykh Muqbil bin Hadi al Wadi'i (d. 2001), who revived the teaching of Salafism in Yemen. Muqbil established his madrasah of Darul Hadīth al-Khayriyya in the province of Sa'da in 1979. This institution then became one of the prominent centers of Salafi teaching in the world (Haykel, 2002). Many of his students were from Indonesia, one of the first being Jafar Umar Thalib. He went to Yemen after leaving the pondok pesantren Tengaran that is owned by the Salafi faction of Al-Irsyad. In 2000, Thalib declared a jihad war in the Maluku Islands with his paramilitary group called Laskar Jihad (Hasan, 2006).

The second factor that pushed the reconnection between Indonesia and Hadhramaut was the Bā 'Alawi in Indonesia's own initiative to re-establish relations with Hadhramaut. Efforts were advanced by figures such as Habib Anis bin 'Alwi al-Ḥabashī (d. 2006), a charismatic Bā 'Alawi preacher from Solo, Central Java. During his lifetime, he was considered one of the leading figures of the Bā 'Alawi in Indonesia. After the unification of Yemen, Habib Anis met with Habib Abdul Qadir Assegaf (d.2010), a Bā 'Alawi from Jeddah, during a maulid program in Seiyun, Yemen. Habib Anis shared with Habib Abdul Qadir how, in his opinion, most of the young Bā 
'Alawi in Indonesia had forgotten their ancestors' teachings. To deal with this, Habib Anis asked for Habib Abdul Qadir's help in finding someone who could come to Indonesia, recruit students, and bring them to study in Yemen. He believed doing this would encourage a deeper understanding of Islam and the traditions of their ancestors among the young Indonesian Bā 'Alawi (Majelis Al-Munawwarah, 2017). Subsequently, Habib Abdul Qadir sent Habib Umar to go to Indonesia to carry out this mission. In 1993, Habib Umar went to see Habib Anis during the annual death commemoration (haul) of Habib 'Ali in Solo. Afterward, he brought students from Indonesia to study with him at his Darul Mustafa madrasah. The first batch of Indonesians to study with Habib Umar consisted of 30 students. Among them, 17 students were Bā 'Alawi, and the rest were indigenous Indonesians (Alatas, 2009; Rijal, 2016).

After four years of studying, these students returned to Indonesia and would hold religious gatherings in their hometowns. Just as Habib Umar faced the Salafi's growing influences in Yemen, his students also faced the same challenge of confronting Salafism in Indonesia. Knysh (2001) explains how Habib Umar, in his dakwah, minimizes the use of narratives surrounding the miracle of the saints used by the Bā 'Alawi. Moreover, he also emphasizes the importance of hadīth in his Sufi teaching. This is partly due to the dispute over religious authority with the Salafis, who mostly use a scriptural approach in criticizing the Sufi practices in Yemen. Furthermore, this style of dakwah is also employed by Habib Umar's students in Indonesia, who underline the use of the Qur'ānic and hadīth explanation in each of their dakwah programs. By implementing this approach, their religious 
gatherings attract the youth who, as of late, have become more interested in Salafism (Alatas, 2009).

Today, the former students of Habib Umar belong to an interconnected network. They establish pondok pesantren and religious gatherings as well as promote Hadhramaut and Darul Mustafa as the center of Islamic studies in the Middle East. Many of them become the intermediary agents for selecting prospective students for Darul Mustafa. As a result, these days, many graduates of Habib Umar can be found in Indonesia. In East Java, for instance, there are more than 200 alumni of Darul Mustafa who actively promote dakwah through regular sermons or Islamic boarding schools (Rijal, 2017).

\section{2. 'Street Sufism' and the Dakwah of Aswaja}

Among Habib Umar's students, one of the most renowned ones, especially in the first decade of the $21^{\text {st }}$ century, was the late Habib Munzir bin Fuad al-Musawa (d. 2013). He was among the first 30 Indonesian students who studied in Darul Mustafa. Upon returning to his birth country, he set up a weekly gathering in Jakarta. He went from one mosque to another or to his followers' homes to perform his dakwah lectures. Due to the program's success, in 2000, he established the religious gathering of Majelis Rasulullah (M.R.) (Guntur, 2013). This gathering was successful in terms of pulling the youth to his religious events.

One of the characteristics of Majelis Rasulullah, as is noted by Alatas (2009), was its scriptural approach of using hadīth and the Qur'ān to attract the youth. This method, as the youth, especially university students in 
Jakarta, are familiar with the Salafi-reformist style. Using this style is also convenient for Munzir, particularly when defending some rituals criticized by the Salafi, such as tawassul and the maulid celebration.

This scriptural approach can be seen, for instance, in the question-and-answer column of the Majelis Rasulullah website. A question by his follower on the ruling of the maulid celebration, Habib Munzir answered by citing several Qur'ānic verses and hadīth on the legality of the celebration. The Qur'ānic verse and hadīth go as follows:

Surah al-Maryam: 33

"And Salam (peace) be upon me the day I was born, and the day I die, and the day I shall be raised alive!" (al-Hilali \& Khan, 1998).

The hadīth:

Abu Qatada Ansari (Allah be pleased with him) reported that Allah's Messenger (may peace be upon him) was asked about fasting on Monday, whereupon he said: It is (the day) when I was born and revelation was sent down to me (Siddiqui, 2009).

By using these two explanations of the Qur'ān and hadīth, Habib Munzir concluded that celebrating the birthday of Prophet Muhammad (pbuh) was allowed (Majelis Rasulullah, 2012). In this regard, he was trying to tackle the maulid criticism of the reformists and the Salafis.

Moreover, Habib Munzir frequently invited his followers to religious rituals that have been preserved by the Bā 'Alawi until today, such as the visitation of gravesites and the maulid celebration. Majelis Rasulullah's 
own maulid celebration is relatively large and attracts many people. Howell and Zamhari (2012) described the program as taking Sufism to the streets or 'street Sufism'. It is described as such because the maulid celebration of Majelis Rasulullah would block off streets in order to create more space for the event to be held. On its official YouTube channel, Majelis Rasulullah can be seen celebrating the maulid by reciting the maulid book of Dhiyamul Lami', which was written by Habib Umar. Its maulid program consists of the full recitation of this maulid book, which is accompanied by the musical percussion group banjari (Majelis Rasulullah, 2013). However, even though there are other branches of Majelis Rasulullah outside the province of Jakarta, it seems that the maulid performance only covers the area of Greater Jakarta.

Another distinctive feature of Habib Munzir (as well as other Bā 'Alawi in Indonesia) is the dakwah for defending aswaja (ahl sunnah wal jam'ah). Aswaja is a Sunni traditionalist version of Indonesia, one that is particularly used by Nahdlatul Ulama (N.U.). According to the organization, aswaja is defined based on three characteristics: in Islamic theology, they follow al-Ash'ari (d. 936) and Abu Mansur al-Maturidi (d. 944); in Islamic law they adopt one of the four schools (Hanafi, Maliki, Shafi'i, or Hanbali), and in Sufism, they apprehend the schools of al-Junaid al-Baghdadi (d. 910) and al- Ghazali (d. 1111). The term aswaja is used by the Bā 'Alawi (as well as N.U. members) to differentiate themselves from the reformist Muslims, especially the Salafis (Rijal, 2016). Defending aswaja for the Bā 'Alawi means opposing the 
Salafis because, according to the Salafis, the Islamic theology of Asy'ariyah and Sufism deviates from the teaching of the first three generations of Muslims (alsalafal-sālih) (al-Munajjid, 2009, 2014).

Habib Munzir's stance on aswaja can be found on the website of Majelis Rasulullah, which displays his statement after a man's question regarding guidance on how to strengthen his belief in aswaja theology. Pertaining to this question, Habib Munzir recommended the man to read his book on Islamic theology, which can be downloaded from the website (Majelis Rasulullah, 2010). Habib Munzir states that aswaja in Islamic theology refers to takwil (allegorical interpretation). According to him, this interpretation is better when compared to another school of tafwid (relegation of matter to God). According to Munzir, the former is followed both by Imam Shafi'i and Imam Bukhari (Al-Musawa, 2009). Furthermore, this aswaja rhetoric is widely used by Habib Munzir and Habib Umar, his students, and almost all Bā 'Alawis in Indonesia.

After Habib Munzir passed away in 2013, Majelis Rasulullah carried on his legacy by practicing the maulid celebration, which has continued until today by his brothers and other Bā 'Alawis in Jakarta. Habib Munzir and other Bā 'Alawi activities in Jakarta (for instance Majelis Nurul Mustofa and Al-Fachriyah Foundation) show how Bā 'Alawi preachers moved to revive religious activities after 2000, especially after the re-establishing ties with Yemen (Alatas, 2009; Al-Fachriyah, 2014; Rijal, 2016). In addition to that, they are actively working to promote the maulid celebration and defending this practice through their 'street Sufism' and online preaching. 
Besides Jakarta, there are other Bā 'Alawi preachers elsewhere in Indonesia who revitalized their traditionalist rituals. Assuredly, this revival owes a debt of gratitude to the role of Habib Anis bin 'Alwi al-Habashī of Surakarta, who suggested for Indonesia to reconnect with Hadhramaut. In his hometown Surakarta, Habib Anis is known for his efforts to preserve the maulid from the 1970s, as well as for inspiring the new style of maulid within popular culture in the $21^{\text {st }}$ century. In the following section, I will discuss the maulid celebration in Surakarta, especially within the Bā 'Alawi community, whose practices were shaped by and inherited from Habib Anis bin 'Alwi al-Ḥabashī.

\section{E. Hadhrami and the Maulid Celebration in Surakarta}

Surakarta or commonly called Solo is a municipality that is located in the province of Central Java. It was the capital of Karesidenan (regentschappen) Solo, which consisted of seven cities: Boyolali, Karanganyar, Klaten, Sragen, Sukoharjo, Surakarta, and Wonogiri. Today, these cities are called Solo Raya (Greater Solo). The municipality of Surakarta has five sub-districts (kecamatan): Banjarsari, Laweyan, Jebres, Pasar Kliwon and Serengan) and 51 villages (kelurahan). The culture of the city is a mixture of traditional Javanese and Islamic. This is due to the existence of the Islamic Mataram kingdom that was founded in the $16^{\text {th }}$ century. Ricklef (2007) describes the culture of the city as Islamic with a strong influence of Javanese identity. In recent times, Surakarta is known for its image as the bulwark of Islamic radical groups (Wildan, 2009). This image stems from the fact that Islamic radicalism 
has been on the rise in the city since 1998. This is represented by some groups such as Front Pemuda Islam Surakarta (FPIS, Muslim Youth Front of Surakarta), Laskar Jundullah, Laskar Hawariyun, Forum Umat Islam (FUI), Majelis Mujahidin (MMI), and Jamaah Anshorut Tauhid (Wildan, 2008). In this city, we can also find the pondok pesantren Ngruki, some of whose graduates were affiliated with terrorist groups in Indonesia. In addition to that, several institutions in this city are affiliated with the Salafis, including radio stations and Islamic boarding schools (Sunarwoto, 2015, 2016), as well as the Islamic reformist movement of Majelis Tafsir al-Qur'ān (Sunarwoto, 2012; Zuhri, 2013).

Regarding the Hadhramis (both Sayyid and non-Sayyid) in Surakarta, based on a statistic from 1885, there were an estimated 71 individuals of Hadhrami origin in Surakarta, three of which were born in Hadhramaut. The rest were born on the archipelago (L.W.C. van den Berg, 1989). The latest estimation of the number of Hadhramis in Surakarta was conducted in 2001, with the number of people amounting to 3.874 (Suhadi, 2014). The Bā 'Alawi mostly live in the subdistrict of Pasar Kliwon. This area was designated for Arabs due to the Dutch policy of the quarter and pass systems (wijkenstelsel and passenstelsel), which required Arabs to reside in one area separated from the local people (de Jonge, 1997). There are four major sites in this sub-district at which the Bā 'Alawi community usually gathers and interacts. The first is the school of the Islamic Educational Foundation of Diponegoro (Yayasan Pendidikan Islam Diponegoro, YPID), which was established in 1928 by Bā 'Alawi figures who were involved in Rabitha' Alawiyah (YPID, 2012), the Jami Mosque of Assegaf, the Riyadh Mosque, and the Khoir Mosque. The last three sites are the places at which the maulid is celebrated. 
Among the three mosques, it is only the Riyadh Mosque that holds maulid every week. The Jami Mosque of Assegaf holds maulid annually on the $12^{\text {th }}$ of the month Rabĩal-Awwal, the date on which the Prophet (pbuh) is believed to be born, and the Khoir Mosque holds it informally at the house of the imam, not inside the mosque.

Unlike the Javanese, who usually recite the maulid book of Barzanjī or Diba'i, Bā 'Alawis in Surakarta (and elsewhere) recite the maulid book of Simthud Durar. This choice is related to the fact that this maulid book is written by one of the charismatic Bā 'Alawi scholars of the Hadhramaut in 1913, Habib 'Ali bin Muhammad al-Habashī (d. 1915). During his life, Habib 'Ali had conducted the celebration of the Prophet's birthday every Thursday night in the Riyadh mosque in the city of Seiyun in Hadhramaut (Boxberger, 2002). By using a maulid book authored by other Bā 'Alawi scholars, the Bā 'Alawi community emphasizes their authority and connection to the Prophet (pbuh) (Alatas, 2009).

Regarding the transfer of the practice of reciting the Simthud Durar to Java, it was the students as well as the descendants of Habib 'Ali bin Muhammad al-Habashī who brought this practice to the Dutch East Indies. One of them was Habib Muhammad bin Idrus al-Ḥabashī (d. 1917), a student of Habib 'Ali and the first person who introduced Simthud Durar in Indonesia. He began in Cirebon before later moving to Bogor. Shortly before the end of his life, he moved to Surabaya where he regularly recited the maulid book of Simthud Durar (Umar Mauladdawilah, 2008). After his death, Habib 'Ali bin Abdurrahman al-Habashī (d. 1968), also known as Habib Kwitang, continued reciting Simthud Durar in Jakarta. 
Habib 'Ali first carried out the maulid in the Jamiat Khair headquarters, but then the practice was moved to a mosque in the village of Kwitang, Central Jakarta. In this mosque, he started to organize annual maulid celebrations in 1918, which attracted thousands of participants, both from Bā 'Alawi and Javanese people (Alatas, 2011; Pijper, 1934). Although this maulid occasionally attracted thousands of people, it seems that many participants came due to Habib 'Ali's charisma.

Simthud Durar was brought to Surakarta by Habib 'Alwi bin 'Ali al-Habashī (d. 1953), the son of its author. He had moved to the Dutch East Indies after the death of his father. At first, he resided in Jakarta before moving to Semarang and then later settling in Surakarta. In 1934, he built a mosque with supplementary buildings which functioned as stores and houses. He named the mosque Riyadh after the mosque in the city of Seiyun that was built by his father. As his father was well known for his maulid book, many Bā 'Alawi in the Dutch East Indies respected Habib 'Alwi.

Consequently, many people came to his mosque to celebrate the maulid or seek his blessing. He died in Palembang in 1953, but his body was transported back to Surakarta and buried at the site of the Riyadh Mosque. After the passing of Habib 'Alwi, the maulid in the Riyadh Mosque was continued by his son, Habib Anis bin 'Alwi al-Habashī (d. 2006). It was under the influence of Habib Anis that Simthud Durar became gradually well-known among Muslims. Following the footsteps of his grandfather in the Hadhramaut, a weekly maulid was conducted every Thursday night. To commemorate the author of Simthud Durar, every month of Rabī al-Thānī (the fourth month of the Islamic calendar), the Riyadh mosque holds the annual death commemoration 
(haul) of Habib 'Ali. In this event, the maulid celebration is performed with the recitation of Simthud Durar (for a detailed account of this haul, see Alatas, 2014; Slama, 2011). In 2014, the municipality of Surakarta incorporated this program into an annual governmental program under the framework of the policy of Solo as "the city of shalawat."

Below, I will explain the maulid celebration performed in the Riyadh Mosque every Thursday night. The data was taken through fieldwork that was done in January and February 2018. The celebration itself starts around 6:00 pm (after the maghrib prayer), but some people often arrive at the mosque several hours in advance. Usually, they first visit the graves of Habib 'Alwi and Habib Anis (besides the mosque), where they pray for the deceased and seek divine baraka (blessing). Other than that, people rest on the floor inside the mosque and wait. Half an hour before Maghrib time, the mosque's front yard is already full of motorcycles of people who want to join the maulid celebration (Fieldnotes, 2018).

After the Maghrib prayer is finished, the maulid starts and is led by Habib Hasan bin Anis al-Habashī (b. 1966). As the great-grandson of the author of Simthud Durar, many people, including the Bā 'Alawi, consider Habib Hasan the most authoritative person to lead the celebration. Imams of other Bā 'Alawi mosques (Assegaf and Al-Khoir) are often seen to attend the Riyadh Mosque to celebrate the maulid. Their participation shows the interconnectedness of the three Bā 'Alawi mosques, as well as the respect for the Riyadh Mosque as the center of the maulid activities in the city of Surakarta.

Before reciting Simthud Durar, Habib Hasan first reads the tawassul (Fieldnotes, 2018). By practicing tawassul, the 
people believe that they can pray for the deceased and get a religious reward without being physically present near the deceased (Millie, 2009). After Habib Hasan recites all the names of the Bā 'Alawī' ulamā', he continues by reciting the first chapter of Al-Qur'ān (al-fatihah), which is then followed by a recitation by the participants. All the participants inside the mosque are men. Women were not seen to be present. However, according to one of my interlocutors, the female participants are located in a separate room so that the male participants could not see them (Personal communication with Mbah Soleh, 30 November 2018).

After the tawassul, the Simthud Durar is recited by Habib Hasan, together with several Bā 'Alawī who sit beside him and take turns in reciting the book. At this event, there are no Javanese who recite Simthud Durar along with the Bā 'Alawi. They only act as passive participants who listen and repeat some verses of the Simthud Durar. The book itself has 14 chapters. There are interludes after the imam has recited some chapters during which another person sings qasidah (Arabic poetry) (Fieldnotes, 2018).

When a person sings a qasidah, five rebana players accompany him. The instruments are not played every week. They are only used on the second and fourth Thursday nights of the month, while on the first and the third Thursday nights, the qasidah is sung without instruments. In terms of the number of participants, the maulid events with the rebana attract more participants than ones without. The rebana in the Riyadh Mosque uses the banjari style. It refers to the name of a city in Banjar, South Kalimantan, from which the style originated. The size of the rebana banjari is $30 \mathrm{~cm}$. This 
rebana style has been used in the Riyadh Mosque since the early 1980s. Before using rebana banjari, the maulid in the Riyadh mosque was only accompanied by two duffs, drums, which were brought from Yemen by Habib 'Alwi (Interview with Mbah Soleh, 15 January 2018).

After reciting Chapter 7 of the book, people stand up for the recitation of the chapter on mahallul qiyām. In this chapter, the leader and all the participants sing a text containing a poem expressing happiness for the birth of Prophet Muhammad (pbuh). During the qiyām, one person passes around burning agarwood to the participants. The participants reach out their hands to the smoke of agarwood incense, and each of them wipes it to their faces. The incense of agarwood is commonly used among the Bā 'Alawi because it gives a sweet fragrance to the room. It is used not only in events like maulid, but also in their religious gatherings.

Moreover, one piece of bread and a glass of coffee with milk are distributed after the qiyām. One of the Hadhrami preachers then delivers a sermon for ten minutes with the topic of thankfulness to God. Following that, the recitation is continued and finished when all fourteen chapters are recited. Habib Ahmad closes the celebration by reciting a supplication. In total, the maulid lasts for almost two hours. The evening is ended by 'Isha prayer in congregation (Fieldnotes, 2018).

Apart from the weekly maulid celebration at the Riyadh Mosque, according to many Bā 'Alawis I encountered, the maulid simthud durar is performed at almost all big celebrations of the Bā 'Alawi, e.g., moving into a new house, animal sacrifice for a newborn baby (aqiqah), marriage proposal, as well as a wedding ceremony. Among the events above, I had the chance to observe the maulid conducted during 
the wedding ceremony of a Bã 'Alawi. In general, all of the above descriptions of the maulid in the Riyadh Mosque apply to the wedding ceremony of the Bā 'Alawi as well, including the fact that Habib Hasan leads it. The only difference is that in the maulid of the marriage event, the qiyām is followed by a marriage vow (Fieldnotes, 2018).

\section{F. Conclusion}

This article has described the arguments for and against the maulid celebration among Indonesian Hadhrami, both Sayyid and non-Sayyid. The former established the Jamiat Khair, while the latter established Al-Irsyad, who contested some religious rituals of the former, such as the maulid celebration. Al-Irsyad, who shared the view of other Islamic reformist organizations on the maulid, did not condemn the maulid, but was merely concerned about some of the practices within the celebration, especially the qiyām.

However, Al-Irsyad's stances shifted in the 21s century when Salafi figures infiltrated the organization and created a split within the group: the reformist of Al-Irsyad Al-Islamiyah and the Salafis of Perhimpunan Al-Irsyad. The main finding of this article has been that these two organizations have different religious stances on rituals, such as the maulid celebration. AlIrsyad Al-Islamiyah preserved the stance of Ahmad Surkati to allow the celebration, while Perhimpunan Al-Irsyad gave a more strict opinion by stating that the maulid is bid'a and recommends its members and followers not to practice it.

Furthermore, the Bā 'Alawi community still maintains the maulid despite many criticisms, one of which comes from Al-Irsyad. The continuation of the maulid celebration is thanks 
to the revival in the relationship between Indonesian Bā 'Alawī with their network in Yemen. One central figure was Habib Umar, who with many of his disciples preserved the maulid. One of them, Habib Munzir, took Sufism to the street and created a large maulid event that has attracted many people. Besides Habib Umar, Habib Anis of Solo also plays a special role in maintaining and inspiring other Bā 'Alawi to preserve their traditional practices, especially the maulid in Surakarta. As the grandson of the author of Simthud Durar, he successfully kept the ritual practices alive since the 1960s in the city.

For further research, more studies should be done on the maulid celebration held by the Bā 'Alawī community. As we have seen recently, popular preachers of the Bā 'Alawī use maulid as part of their dakwah strategy. Such preachers include Habib Syech bin Abdul Qadir Assegaf from Surakarta and his shalawat group of Ahbabul Mustofa, as well as Habib 'Ali Zainal Abidin with his group Al-Zāhir in Pekalongan. It is interesting to explore whether these groups preserve the old style of maulid or modify it to attract more participants to their religious gatherings.

\section{REFERENCES}

Abu Shouk, A. I. (2002). An Arabic manuscript on the life and career of Ahmad Muhammad Surkati and his Irshadi disciples in Java. In N. and H. de J. Kaptein (Ed.), Transcending Borders: Arabs, politics, trade and Islam in Southeast Asia (pp. 203-218). KITLV Press.

Affandi, B. (1976). Shaykh Ahmad Al-Surkati: His Role in al-Irshad Movement in Java in the Early Twentieth Century. Mcgill University. 
al-Munajjid, S. (2009). Sufi tareeqahs and the ruling on joining them-Islam Question \& Answer. https://islamqa.info/ en/answers/20375/sufi-tareeqahs-and-the-ruling-onjoining-them

al-Munajjid, S. (2014). Siapakah Asya'ariyyah Itu?, Apakah Mereka Termasuk Ahlus Sunnah? - Soal Jawab Tentang Islam. https://islamqa.info/id/answers/226290/siapakahasyaariyyah-itu-apakah-mereka-termasuk-ahlus-sunnah

Alatas, I. F. (2009). Securing Their Place: The Ba Alawi Propethic Piety \& Islamic Resurgence in Indonesia. National University of Singapore.

Alatas, I. F. (2011). Becoming Indonesians: The Ba 'Alawi in the Interstices of the Nation. Die Welt Des Islams, 51, 45-74.

Alatas, I. F. (2014). Pilgrimage and Network Formation in Two Contemporary Ba 'Alawi Hawl in Central Java. Journal of Islamic Studies, 25(3), 298-324.

Alatas, I. F. (2016). Aligning the Sunna and the Jama'a: Religious Authority and Islamic Social Formation in Contemporary Central Java, Indonesia.

Al-Fachriyah. (2014). Sejarah Berdiri Al Fachriyah. Al-Fahcriyah. https://www.alfachriyah.org/menu/tentang-kami/ sejarah-berdiri-al-fachriyah/

al-Hilali, M. T.-D., \& Khan, M. (1998). The Noble Qur'an: English Translation of the Meanings and Commentary. King Fahd Complex for the Printing of the Holy Qur'an.

Al-Irsyad.(2017, November25).SDAlIrsyadAlIslamiyyahJemberPosts [Facebook Post]. Menyambut Maulid Nabi SAW 1439. https://www.facebook.com/797906070266085/posts/bercerita-islami-menyambut-maulid-nabi-saw-1439-hdengan-tema-kelahiran-dan-mas/1593921340664550/ 
Al-Musawa, H. M. (2009). Kenalilah Akidahmu 2. Majelis Rasulullah.

As'ad, M. (2019). The Muhammadiyah Criticism Against Mawlid Tradition Over Centuries. JOURNAL OF INDONESIAN ISLAM, 13(2), 350-372.

Boxberger, L. (2002). On the Edge of Empire: Hadhramawt, Emigration, and the Indian Ocean, 1880s-1930s. State University of New York Press.

Bujra, A. S. (1967). Political conflict and stratification in Hadramaut-I. Middle Eastern Studies, 3(4), 355-375.

de Jonge, H. (1993). Discord and Solidarity among the Arabs in the Netherlands East Indies, 1900-1942. Indonesia, April(55), 73-90.

de Jonge, H. (1997). Dutch Policy Pertaining to Hadhrami Immigrants. In W. Freitag, Ulrike; Clarence-Smith (Ed.), Hadhrami Traders, Scholars and Statesmen in the Indian Ocean, 1750s to 1960s.

Guntur, M. dan T. M. R. (2013). Habib Munzir Menanam Cinta untuk Para Kekasih Rasulullah. Qultum Media.

Haikal, H. (1986).Indonesia-Arab dalam Pergerakan Kemerdekaan Indonesia (1900-1942). Universitas Indonesia.

Hasan, N. (2006). Laskar Jihad: Islam, Militancy, and the quest for identity in post-new order Indonesia. Southeast Asia Program Publications, Cornell University.

Haykel, B. (2002). The Salafis in Yemen at a Crossroads: An Obituary of Shaykh Muqbil al-Wadi'i of Dammaj (d. 1422/2001). Jemen Report, October(27-31). 
Hijrah. (2016). Apakah Salah Tidak Mengikuti Maulid Nabi? Dr. Khalid Bassalamah, MA. https://www.youtube.com/ watch?v=71hh7cnvzaQ

Kaptein, N. (1993). The Berdiri Mawlid Issue among Indonesian Muslims in the period from circa 1875 to 1930. Bijdragen Tot de Taal-, Land- En Volkenkunde, 149(1), 124-153.

Knysh, A. (2001). The "Tariqa" on a Landcruiser: The Resurgence of Sufism in Yemen. Middle Eastern Studies, 55(3), 399-414.

Knysh, A. (2003). Contextualizing the Salafi-Sufi conflict (From the Northern Caucasus to Hadramawt). Middle Eastern Studies, 43(4).

Lentera Islam. (2016, June 29). Asal sejarah Mauilid Nabi dan Apakah maulid termasuk bid'ah hasanah? Ustadz DR Khalid Basalamah, MA. https://www.youtube.com/ watch?v=Be1QWiYoCuQ

L.W.C. van den Berg. (1989). Hadrami dan Koloni Arab di Nusantara (R. Hidayat, Ed.). INIS.

Majelis Al-Munawwarah. (2017). Awal Mula Kedatangan Habib Umar bin Hafidz di Indonesia. Majelis Al-Munawwarah. http://majelisalmunawwarah.blogspot.com/2017/01/ awal-mula-kedatangan-habib-umar-bin.html

Majelis Rasulullah. (2010). Agar istiqomah terhadap aqidah aswaja. Majelis Rasulullah. http://www.majelisrasulullah.org/ forums/topic/agar-istiqomah-terhadap-aqidah-aswaja/

Majelis Rasulullah. (2012). Bid'ah. Majelis Rasulullah. http:// www.majelisrasulullah.org/forums/topic/bidah/

Majelis Rasulullah. (2013). Badr2010. Majelis Rasulullah. https:// www.youtube.com/watch?v=F2JkRRm7wTw\&t=3040s 
Miftahuddin. (2013). Dinamika Gerakan Al-Irsyad: Studi Pola Pembahanmn dan Pembahan Identitas Kaum Hadrami, 1945-2007 [Research Report]. Universitas Negeri Yogyakarta. http://lppm.uny.ac.id/sites/lppm.uny.ac.id/ files/Abstrak\%20Al-Irsyad.pdf

Millie, J. (2009). Splashed by the Saint, Ritual Reading and Islamic Sanctity in West Java. KITLV Press.

Mobini-Kesheh, N. (1999). The Hadrami Awakening; Community and Identity in the Netherlands East Indies, 1900-1942. Southeast Asia Program Publications, Cornell University.

Muslim Belajar. (2017). Hukum perayaan maulidUstadz Firanda Andirja. https://www.youtube.com/ watch?v=2KAC6vpFj44

Noer, D. (1963). The Rise and Development of the Modernist Muslim Movement in Indonesia during the Dutch Colonial Period (1900-1942). Cornel University.

Noer, D. (1973). Modernist Muslim Movements in Indonesia. Oxford University Press.

Perhimpunan Al-Irsyad. (2019). Anggota Dewan Fatwa Perhimpunan Al-Irsyad.

Pijper, G. F. (1934). Fragmenta Islamica: Studien over het Islamisme in Nederlandsch-Indie. Brill, E.J.

Qendaly, U. F. B. M. (2011). Biografi 45 Habib Nusantara. Darul Hikmah. Republika. (2017). Ketum Al-Irsyad: Maulid Nabi Bukan Sekedar Peringatan. Republika. https://www.republika. co.id/berita/dunia-islam/islam-nusantara/17/12/01/ p09zxh385-ketum-al-irsyad-maulid-nabi-bukan-sekedarperingatan 
Ricklefs, M. C. (2007). Polarising Javanese Society, Islamic and other visions c. 1830-1930. KITLV Press.

Rijal, S. (2016). Habaib, Markets and Traditional Islamic Authority: The Rise of Arab Preachers in Contemporary Indonesia. The Australian National University.

Rijal, S. (2017). Internal Dynamics within Hadhrami Arabs in Indonesia. Journal of Indonesian Islam2, 11(1), 1-28.

Salam Dakwah. (2014). Bidah Hasanah. https://www.youtube. com/watch?v=VE_6XBh40IY\&t=11s

Sang Pendoa. (2017, August 10). Sholawatan Populer Tapi Bukan dari Rasulullah, Tinggalkan saja. https://www.youtube. com/watch?v=aIpqxzJMj1k\&t=142s

Siddiqui, A. al-H. (2009). English Translation of Sahih Muslim. islamhouse.com.

Slama, M. (2011). Paths of Institutionalization, Varying Division, and Contested Radicalism: Comparing Hadhrami Communities on Java and Sulawesi. Comparative Studies of South Asia, Africa and the Middle East, 31(2), 331-342.

Slama, M. (2014). Indonesian Hahdramis and the Hadhramaut: An Old Diaspora and its New Connections. Antropologi Indonesia, June.

Suhadi. (2014). I Come from a Pancasila Family: A Discursive Study on Muslim-Christian Identity Transformation in Indonesian Post-Reformasu Era. LIT Verlag.

Sunarwoto. (2012). Radio Fatwa: Islami Tanya-Jawab Programmes on Radio Dakwah. Al-Jamiah, 50(1).

Sunarwoto. (2015). Contesting Religious Authority: A Study on Dakwah Radio in Surakarta. Tilburg University. 
Sunarwoto. (2016). Salafi Dakwah Radio: A Contest for Religious Authority. Archipel, 91, 203-230.

Surkati, A. (1988). Tiga Persoalan. Pimpinan Pusat al-Irshad.

TauhidSquad.(2016).MaulidNabiBid'ah?-UstadzFirandaAndirja. https://www.youtube.com/watch?v=1DCXwoXeXG4

Umar Mauladdawilah, A. Q. (2008). 17 Habib Berpengaruh di Indonesia. Pustaka Bayan.

Wildan, M. (2008). Mapping Radical Islamism in Solo: A Study of the Proliferation of Radical Islamism in Central Java, Indonesia. Al-Jamiah, 446(1).

Wildan, M. (2009). Radical Islamism in Solo: A Quest of Muslims' Identity in A Town of Central Java Indonesia. University Kebangsaan Malaysia.

YPID. (2012). Selayang Pandang Sejarah Berdirinya Yayasan Pendidikan Islam Diponegoro. YPID. https://ypid. or.id/selayang-pandang-sejarah-berdirinya-yayasanpendidikan-islam-diponegoro-surakarta/

Zamhari, A., \& Howell, J. D. (2012). Taking Sufism to the streets: Majelis zikir and majelis salawat as new venues for popular Islamic piety in Indonesia. RIMA: Review of Indonesian and Malaysian Affairs, 46(2), 47-75.

Zuhri, S. (2013). Majlis Tafsir Al-Qur'an and its struggle for Islamic reformism. In J. and K. van D. Burhanuddin (Ed.), Islam in Indonesia, Contrasting Images and Interpretations (pp. 227-240). Amsterdam University Press. 


\section{Websites}

Al-Fachriyah. (2014). Sejarah Berdiri Al Fachriyah. Al-Fahcriyah. Retrieved March 5, 2019, from https://www.alfachriyah. org/menu/tentang-kami/sejarah-berdiri-al-fachriyah/.

al-Munajjid, S. (2009). Sufi tareeqahs and the ruling on joining them-Islam Question \& Answer. Retrieved November 16, 2019, from https://islamqa.info/en/answers/20375/ Sufi-tareeqahs-and-the-ruling-on-joining-them.

al-Munajjid, S. (2014). Siapakah Asya'ariyyah Itu?, Apakah Mereka Termasuk Ahlus Sunnah? - Soal Jawab Tentang Islam. Retrieved November 16, 2019, from https:// islamqa.info/id/answers/226290/siapakah-asyaariyyahitu-apakah-mereka-termasuk-ahlus-sunnah.

Al-Irsyad. (2017, November 25). SD Al Irsyad Al Islamiyyah Jember-Posts [Facebook Post]. Menyambut Maulid Nabi SAW 1439. Retrieved November 11, 2019, from https://www.facebook.com/797906070266085/posts/bercerita-islami-menyambut-maulid-nabi-saw-1439-hdengan-tema-kelahiran-dan-mas/1593921340664550/.

Hijrah. (2016). Apakah Salah Tidak Mengikuti Maulid Nabi? - Dr. Khalid Bassalamah, MA. Retrieved November 10, 2019, from https://www.youtube.com/watch?v=71hh7cnvzaQ.

Lentera Islam. (2016, June 29). Asal sejarah Mauilid Nabi dan Apakah maulid termasuk bid'ah hasanah? Ustadz DR Khalid Basalamah, MA. Retrieved November 10, 2019, from https://www.youtube.com/watch?v=Be1QWiYoCuQ.

Majelis Al-Munawwarah. (2017). Awal Mula Kedatangan Habib Umar bin Hafidz di Indonesia. Majelis Al-Munawwarah. Retrieved September 11, 2019, from http:// 
majelisalmunawwarah.blogspot.com/2017/01/awalmula-kedatangan-habib-umar-bin.html.

Majelis Rasulullah. (2010). Agar istiqomah terhadap aqidah aswaja. Majelis Rasulullah. Retrieved September 11, 2019, from http://www.majelisrasulullah.org/forums/topic/ agar-istiqomah-terhadap-aqidah-aswaja/.

Majelis Rasulullah. (2012). Bid'ah. Majelis Rasulullah. Retrieved September 11, 2019, from http://www.majelisrasulullah. org/forums/topic/bidah/.

Majelis Rasulullah. (2013). Badr2010. Majelis Rasulullah. Retrieved September 11, 2019, from https://www. youtube.com/watch?v=F2JkRRm7wTw\&t=3040s.

Muslim Belajar. (2017). Hukum perayaan maulid-Ustadz Firanda Andirja. Retrieved October 02, 2019, from https:// www.youtube.com/watch?v=2KAC6vpFj44.

Republika. (2017). Ketum Al-Irsyad: Maulid Nabi Bukan Sekedar Peringatan. Retrieved September 11, 2019, from Republika. https://www.republika.co.id/berita/duniaislam/islam-nusantara/17/12/01/p09zxh385-ketum-alirsyad-maulid-nabi-bukan-sekedar-peringatan.

Salam Dakwah. (2014). Bidah Hasanah. Retrieved October 02, 2019, from https://www.youtube.com/ watch?v=VE_6XBh40IY\&t=11s.

Sang Pendoa. (2017, August 10). Sholawatan Populer Tapi Bukan dari Rasulullah, Tinggalkan saja. Retrieved October 02, 2019, from https://www.youtube.com/ watch?v=aIpqxzJMj1k\&t=142s.

Siddiqui, A. al-H. (2009). English Translation of Sahih Muslim. Retrieved October 03, 2019, from islamhouse.com. 
Tauhid Squad. (2016). Maulid Nabi Bid'ah? - Ustadz Firanda Andirja. Retrieved October 02, 2019, from https://www. youtube.com/watch?v=1DCXwoXeXG4.

YPID. (2012). Selayang Pandang Sejarah Berdirinya Yayasan Pendidikan Islam Diponegoro. YPID. Retrieved January 13, 2018, from https://ypid.or.id/selayang-pandang-sejarahberdirinya-yayasan-pendidikan-islam-diponegorosurakarta/. 